\title{
Implementation of Tourism Destination Development Policy in Samosir Regency
}

\author{
Kariaman Sinaga \\ Fakultas Pasca Sarjana \\ Universitas Sumatera Utara Medan \\ Medan, Indonesia \\ sinagakariaman@yahoo.com
}

\author{
Suwardi Lubis, Marlon Sihombing, and Ritha \\ Dalimunthe \\ Fakultas Pasca Sarjana \\ Universitas Sumatera Utara Medan \\ Medan, Indonesia \\ sinagakariaman@yahoo.com
}

\begin{abstract}
The development of tourist destinations in Samosir district is an urgent demand for immediate implementation through policies that can build synergy between government, private and community. National regulations should be able to collaborate with tourism destination development policies in the regions in order to run effectively and efficiently. The importance of tourism destination development because it has a broad impact on the life of the community (mulflier effect) so that it can become a high political phenomenon related to power in local government as well as central government. To achieve the success of the development of tourist destinations required the concept of regional development, political and administrative linkages are strong, and empowerment of the community. The role of entrepreneurship is needed in the development of tourist destinations so that people can benefit directly from the development of tourist destinations. Although through a slow process but the participation of the community into demands as per regional autonomy as part of the democratic process in Indonesia. Samosir Regency Government is not ready in determining the policy in the implementation of the development of tourist destinations so that the utilization of the existing potential has not been able to run as expected.
\end{abstract}

Keywords—implementation, policy, development, destination

\section{INTRODUCTION}

Failure to develop tourist destinations is largely due to the failure of political and administrative action functions rather than economic or business functions (Stoker: 1998) in David Airey (2015). The ideology of neoliberalism has become a challenge for the central government and local governments to prove their ability to run the concept of tourism destination development in accordance with their potential.

The development of tourist destinations is an indispensable thing for a region in order to increase regional income and community welfare. The potential that exists in the region is an attraction for tourists both domestic and foreign tourists to travel that will have a widespread impact on society. To achieve the success of tourism destination development is determined by the implementation of policies that really can take advantage of natural resources and human resources in the area.
Nationally the development of tourist destinations is a program of serious concern because it has a strategic position in the development of Indonesia. Through the development of tourist destinations will have a broad impact (multiflier effect) on many other aspects of development. Thus the program of development of destinations undertaken required to synergize with the private sector and society in order to achieve the objectives as expected.

Samosir regency government has determined that tourism is part of the vision of development that will be achieved but the implementation is not strong enough for its achievement. Policies related to the development of tourist destinations in the form of rules relating to the development of tourist destinations is still in the discourse. This is a problem that has a real impact on the achievement of the vision of the government of Samosir Regency.

The natural and cultural potentials that attract tourists are not maximized because they are not supported by the rules in the development of destinations. Tourism becomes political promises that only become an attraction as planned development of Lake Toba Region As one of the national strategic tourism areas.

\section{DISCUSSION}

\section{A. Concept of Regional Development}

In the development of the area on which the development is based, it must pay attention to various aspects, so that the development can be widely accepted by the community. Along with the implementation of regional autonomy, local governments have wider powers in developing tourism destinations. In the wider context as an area of Lake Toba it is necessary to have synergies so that the development is not partial (Raja: 2016).

Solahuddin (2001), Damanik (2016) in Raja (2016) stated that the weakness in the development of tourist destinations around the Lake Toba area is the low quality of tourism services and the lack of innovation to promote the attraction of available attractions. The development of tourist destinations can be seen through: tourist visits, tourism institutionalization, accessibility, facilities, economic psychographic, local cultural 
profile, policy profile, community participation, and institutions.

The development of tourist destinations is a continuation of planning in a region. Sirojuzilam (2008) says regional development planning is an organized effort to set regional economic development goals, collect and evaluate various activities within the framework of strategic regional development.

\section{B. Political and Administrative Relation}

Government policies is top down, should be collaboratively with local governments through structured governance. Through collaborative policies will result in sustainable tourism policies that involve socio-economic communities in order for policies to work effectively. Implementation of government policies requires transparency, legality, benefits, and participation (Graziella Benedetto et al., 2015).

The government should produce policies that can be the basis for managing the development of tourist destinations. This is the key to make a tourist destination a tourist choice. The process of collaboration of stakeholders both individuals and organizations through government policy must be conducted through analysis bersma or unilateral.

If not immediately anticipated, neoliberalism's ideology will affect government regulation as well as non-governmental institutions characterized by strong privatization of the neoliberalization itself (Stoker: 1998) in David Airey (2015). The power of government will be weak in carrying out the development of destinations as expected in concept of governance.

Richter (1989) in David Airey (2015) states tourism is a high political phenomenon and is closely related to public policy. Success in tourism management is a benchmark in a leader's success. As it is understood that the development of tourist destinations has a broad impact in the community so it is very influential in the implementation of a government in the region.Pemberdayaan Masyarakat

Government bureaucracy should be directed to support or facilitate the rise of social entrepreneurship. In New Zealand and Israel countries almost all rural tourism businesses are based on small and medium entrepreneurs. This is a source of income that is a solution to the reduction of traditional agriculture industries (Sharpey: 2000 in Zajadaez: 2016). Through social entrepreneurship will provide solutions to social problems and will strengthen social capital in an area.

Improvement of community empowerment is done through the synergy of four pillars that become stakeholders that are tourists, business, society and government. It is geared towards the best service for tourists. The role of stakeholders will result in a sustainable service system in accordance with local history and culture in the region (Peng.Kang Lin and M.C.Lin: 2016).

The national identity seen from national culture is not abstract values but values that are intentionally and organized are formed through a series of policies. The policy is a tool for developing control within the internal structure to penetrate and internalize traditional values and contemporary values that are considered relevant and functional in the life of society and state (Dirlik: 1999) in Indri Dwi Apriliyani (2014).

In the development of tourist destinations must go through the exploration stage, stage of attachment, development stage and stagnation stage. This is done so that the development of tourist destinations that do not occur so that every stakholder leap the process of developing tourist destinations in a transparent. An important variable in tourism destination development is government policy related to the existence and legitimacy of tourism related to master plan or regulation and community response related to tourism destination management. (Raja: 2016)

\section{CONCLUSION}

The development of tourist destinations is an urgent demand to be managed well because it has a broad impact on society. However, in the development of the destination must be based on the historical and cultural values that exist in an area. This is necessary so that the development of the destination can be run continuously in accordance with the potential of human resources and natural resources owned.

\section{REFERENCES}

[1] Airey, David. Perkembangan dan Memahami Kebijakan Pariwisata. Tourism Review,Vol.70.Iss 4Tahun 2015 hlm 246-247

[2] Benedetto, Graziella et all.Tata Kelola Pariwisata Berkelanjutan. Procedia Environmental Sciences, (2016) 38-40

[3] Dwi, Indri.Apriliyani. Mozaik Kebijakan Publik Di Indonesia,Pustaka Pelajar,Yogyakarta. 2014.

[4] Lumbanraja, Viktor.Diferensiasi Perkembangan Destinasi Wisata Melalui Asumsi Butler (1980), Journal Of Geography UGM Vol.44 No.2 Desember 2012 : 150-160

[5] Peng.Kang-Lin dan Peacl M.C.Lin.Social Entrepreneur: Innovating Rural Tourism Through The Activism Of Service Science, International Journal Of Contemporary Hospitality Management Vol.28, No.6, 2016 pp.1225-1244

[6] Sirojuzilam..Disparitas Ekonomi \&Perencanaan Regional.Pustaka Bangsa Press.Medan. 2008

[7] Zajadaezs, Alina.Evolution Of Disability Models As a The Basis For Further Policy Changes.Jurnal International Journal Hospitality Management Social Entrepreneur.Futures 1 Iss 3Tahun2016 pp 189 202.Faculty of Geography and Geology University Poznan.Poland. 